\title{
KINERJA KEUANGAN DAN TINGKAT BAGI HASIL DEPOSITO MUDHARABAH PADA BANK UMUM SYARIAH DI INDONESIA
}

\author{
Umiyati dan Shella Muthya Syarif \\ Fakultas Ekonomi dan Bisnis, \\ UIN Syarif Hidayatullah Jakarta \\ Email: umivati@uinjkt.ac.id
}

\begin{abstract}
This research aims to analyze the effect of Return On Asset (ROA), Capital Adequacy Ratio (CAR) and BOPO to the level of profit sharing mudharaba deposits Islamic Banks in Indonesia's period January 2011 - June 2015. The data used in this study are monthly data from January 2011 to June 2015. Technical sampling used in this research is purposive sampling, with a sample of 12 Islamic Banks recorded in data from Bank Indonesia. This study uses a computer program SPSS version 20.0 and Microsoft Excel 2007. The result in this research showed that Return On Asset (ROA) and Capital Adequacy Ratio (CAR) partially have significant effect on the level of profit sharing mudharaba deposits While the partial BOPO haven't significant effect of the level of profit sharing mudharaba deposits Simultaneously, Return On Asset (ROA), Capital Adequacy Ratio (CAR) and BOPO had significant effect on the level of profit sharing mudharaba deposits The results also show that variable Return On Asset (ROA) the most dominant on the level of profit sharing mudharaba deposits with the value $\beta$ of $-0,273$, and a significance value smaller than $0,05(0,000<0,05)$.
\end{abstract}

Keywords: Return On Asset (ROA), Capital Adequacy Ratio (CAR), Operating Expenses to Operations Revenue (BOPO) and Level of Profit Sharing Mudharaba Deposits.

\section{PENDAHULUAN}

Bank syariah merupakan bank yang kegiatannya mengacu pada hukum Islam, dan dalam kegiatannya tidak membebankan bunga maupun tidak membayar bunga kepada nasabah. Imbalan yang diterima oleh bank syariah maupun yang dibayarkan kepada nasabah tergantung dari akad dan perjanjian antara nasabah dan bank. Perjanjian (akad) yang terdapat di perbankan syariah harus tunduk pada syarat dan rukun akad sebagaimana diatur dalam syariah Islam (Ismail, 2010).

Pada Undang-Undang No. 21 Tahun 2008 tentang Perbankan Syariah disebutkan bahwa terdapat tiga bentuk perbankan syariah di Indonesia, yaitu Bank Umum Syariah (BUS), Unit Usaha Syariah (UUS), dan Bank Pembiayaan Rakyat Syariah (BPRS). Perkembangan bank syariah di Indonesia masih belum optimal, baik dari segi jumlah bank, jumlah kantor, maupun jumlah asetnya. Pada Outlook Perbankan Syariah 2014 tercatat pertumbuhan aset Bank Umum Syariah dan Unit Usaha Syariah per Oktober 2013 yakni $31,8 \%$ atau mengalami perlambatan pertumbuhan dibandingkan 
tahun 2012 yaitu sebesar 34,1\%. Dari posisi deposit account sebanyak 12,3 juta (9,2\% dari nasional). Selain itu, market share perbankan syariah terhadap perbankan nasional saat ini telah mencapai 4,8\%. Market share perbankan syariah tersebut masih sangat kecil (Rafika, 2015).

Pendirian Bank Syariah saat ini sudah semakin pesat, berdasarkan Statistik Perbankan Syariah periode 2011-2015, sudah ada 12 (dua belas) Bank Umum Syariah (BUS), 22 (dua puluh dua) Unit Usaha Syariah (UUS), 161 (seratus enam puluh satu) Bank Pembiayaan Rakyat Syariah (BPRS).

Persaingan antar perbankan dalam meningkatkan kualitas pelayanan untuk menarik nasabahnya juga semakin tinggi. Beragam jasa pelayanan yang diberikan oleh bank juga mengalami perkembangan. Berbagai penelitian menemukan bahwa perilaku nasabah dalam memilih bank syariah didorong oleh faktor memperoleh keuntungan (Andryani, 2012).

Apriandika (2011), menyatakan besarnya bagi hasil yang diperoleh, ditentukan berdasarkan keberhasilan pengelola dana untuk menghasilkan keuntungan. Oleh karena itu tingkat laba bank syariah bukan saja berpengaruh terhadap tingkat bagi hasil untuk para pemegang saham, tetapi juga berpengaruh terhadap bagi hasil yang dapat diberikan kepada nasabah yang menyimpan dana (konsep profit dan loss sharing). Dengan demikian kemampuan manajemen untuk melaksanakan fungsinya sebagai penyimpan harta, pengusaha dan pengelola investasi yang baik (professional investment manager) akan sangat menentukan kualitas usahanya sebagai lembaga intermediary dan kemampuannya menghasilkan laba.

Produk penghimpunan dana (funding) pada perbankan syariah dapat berbentuk giro, tabungan dan deposito. Salah satu produk dana yang banyak diminati yaitu deposito mudharabah, di mana bank syariah bertindak sebagai mudharib (pengelola dana) sedangkan nasabah bertindak sebagai shahibul maal (pemilik dana) dalam kapasitasnya sebagai mudharib. Bank syariah dapat melakukan berbagai macam usaha yang tidak bertentangan dengan prinsip syariah serta mengembangkannya, bank syariah akan membagihasilkan kepada pemilik dana atau pemilik deposito sesuai dengan nisbah yang telah disepakati dan telah dituangkan dalam akad.

Diantara produk-produk Dana Pihak Ketiga (DPK) bank syariah itu, deposito mudharabah merupakan produk penghimpunan dana yang memberikan proporsi terbesar terhadap total DPK bank syariah. Deposito mudharabah merupakan produk investasi tidak terikat pihak ketiga pada bank syariah yang penarikannya hanya dapat di lakukan pada waktu tertentu dengan pembagian usaha sesuai nisbah yang disepakati di awal pembukaan rekening (www.republika.co.id).

Berdasarkan data statistik Perbankan Syariah Bank Indonesia tahun 2015, sumber dana utama yang ada di perbankan syariah khususnya BUS dan UUS yaitu dana dari pihak ketiga yaitu sebesar $80 \%$. Ini berarti dana terbesar yang dimiliki oleh perbankan bersumber dari masyarakat umum yang menyimpan uangnya di perbankan syariah tersebut. Selain itu sumber dana dari modal sendiri sebesar $15 \%$ dan kewajiban kepada bank lain sebesar $4 \%$. 
Dari tahun 2011-2015 kinerja penghimpunan dana perbankan syariah (BUS dan UUS) selalu mengalami peningkatan.

Peningkatan penghimpunan dana yang berhasil dihimpun BUS dan UUS pada Desember 2011 sebesar Rp.115.415 miliar, tahun 2012 sebesar Rp 147.512 miliar, tahun 2013 sebesar Rp. 183.534 miliar, tahun 2014 sebesar 217.858 miliar, dan bulan Juni 2015 sebesar Rp 215.339 miliar. Penghimpunan dana dari 2009-2010 perbankan syariah sempat mengalami peningkatan yang lambat, namun memasuki pertengahan 2010 mulai mengalami perkembangan yang tinggi (Statistik Perbankan Syariah, 2015).

Kinerja penghimpunan dana perbankan syariah memasuki triwulan III 2010 mulai mengalami perkembangan dengan laju pertumbuhan 39,16\%, lebih tinggi dibandingkan periode yang sama di 2009 sebesar 35,19\%. Tingginya pertumbuhan DPK tersebut didorong oleh semakin kompetitifnya imbal bagi hasil yang ditawarkan bank syariah, meskipun secara umum sepanjang tahun 2010 suku bunga deposito bank konvensional cenderung meningkat namun dengan peningkatan kinerja pembiayaannya, bank syariah dapat memberikan imbal bagi hasil yang tinggi (Bank Indonesia, 2011).

Menurut hasil analisis Ulfah (2010), kenaikan jumlah dana pihak ketiga disebabkan karena beragamnya produk-produk yang dimiliki perbankan syariah dan pelayanan yang relatif baik. Pertumbuhan jumlah DPK juga menunjukan semakin banyaknya masyarakat yang menyimpan dananya di bank-bank syariah. Hal ini juga menunjukkan tingkat kepercayaan masyarakat pada bank syariah.

Berdasarkan data yang dilaporkan dalam Statistik Perbankan Syariah pada tahun 2011-2015, jumlah deposito mudharabah yang di himpun oleh perbankan syariah mengalami peningkatan dari Rp 70.80 triliun menjadi Rp 129.8 triliun. Dalam rentang waktu lima tahun, jumlah deposito mudharabah telah tumbuh sebesar 207,48 persen. Selain itu, dilihat dari proporsinya terhadap total DPK, proporsi deposito mudharabah selama periode tahun 2011-2015 juga mengalami peningkatan dari 57,9 persen menjadi 62,3 persen.

Kondisi persaingan antar bank kini semakin ketat. Dalam menghadapi persaingan, bank syariah perlu mengetahui serta menjaga kesehatan banknya. Untuk mengetahui tingkat kesehatan bank dapat dilihat dari analisis laporan keuangan bank tersebut. Laporan keuangan merupakan sebuah informasi yang penting dalam mengukur tingkat kinerja keuangan bank untuk melakukan investasi. Keuangan yang biasanya disajikan dalam manajemen perbankan yang lazim digunakan dalam memprediksi keuntungan yang diperoleh meliputi neraca, laporan laba rugi dan laporan bagi hasil. Hal ini tidak relevan jika tidak menggunakan analisis rasio keuangan yang biasanya menjadi alat ukur suatu bank untuk mengetahui apakah kinerja keuangan yang selama periode berjalan menguntungkan bagi bank dalam mengolah dana nasabah atau malah merugikan bank.

Berdasarkan data statistik Perbankan Syariah Bank Indonesia Tahun 2011-2015, pengukuran kinerja keuangan yang saat ini diwakili oleh ROA terjadi fluktuatif dari tahun ke tahun yakni pada tahun 2011 sebesar 1,79\% 
tahun 2012 mengalami kenaikan sebesar 2,14\%. Kemudian mengalami penurunan pada tahun 2013 sebesar 2,00\% dan seterusnya. Hal yang sama pun terjadi pada CAR dan BOPO yang mengalami fluktuasi dari tahun ke tahun. Oleh karena itu perlu diteliti kembali mengenai kinerja keuangan yang dapat mempengaruhi secara langsung terhadap tingkat bagi hasil mudharabah.

Kinerja keuangan yang digunakan dapat menunjukkan kualitas bank melalui perhitungan rasio keuangannya. Rasio keuangan yang akan digunakan adalah rasio-rasio keuangan yang konsisten digunakan info bank dalam mengukur kinerja keuangan yang diantaranya Rasio Profitabilitas dengan indikator yang digunakan adalah Retrun On Assets (ROA), Rasio Kecukupan Modal dengan Capital Adequacy Ratio (CAR) dan Rasio Efisiensi dengan Beban Operasional terhadap Pendapatan Operasional (BOPO).

Tingkat profitabilitas adalah tingkat kemampuan bank untuk mendapatkan laba dari setiap pengelolaan dana yang dimiliki. Rasio profitabilitas mengukur efektivitas manajemen berdasarkan hasil pengembalian yang dihasilkan dari pinajman dan investasi. Salah satu indikator yang digunakan untuk mengukur kinerja profitabilitas bank dalam penelitian ini adalah Return on Assets (ROA) yaitu rasio yang digunakan untuk mengukur keuntungan bersih yang diperoleh bank dari penggunaan aktiva bank (Gundari, 2015).

Return on Assets ROA digunakan dalam pengukuran kinerja bank karena apabila ROA meningkat maka pendapatan bank juga meningkat. Dengan adanya peningkatan pendapatan bank maka tingkat bagi hasil yang diterima oleh nasabah juga meningkat. Hasil penelitian yang dilakukan Siti Rahayu (2013) menunjukkan bahwa apabila ROA mengalami kenaikan maka akan menyebabkan peningkatan pada tingkat bagi hasil deposito mudharabah.

Rasio kecukupan modal diwakili dengan Capital Adequacy Ratio (CAR). CAR adalah rasio kecukupan modal yang harus disediakan untuk menjamin dana deposan. Tujuannya adalah agar likuiditas atau kemampuan bank membayar kepada deposan cukup terjamin. Modal merupakan salah satu faktor penting dalam rangka pengembangan usaha bisnis dan menampung resiko kerugian, semakin tinggi CAR maka semakin kuat kemampuan bank tersebut untuk menanggung resiko dari setiap kredit atau aktiva produktif yang berisiko. Jika nilai CAR tinggi (sesuai ketentuan BI $8 \%$ ) maka bank tersebut mampu membiayai operasi bank, keadaan yang menguntungkan bank tersebut akan memberikan kontribusi yang sangat besar bagi profitabilitas dan tentunya akan meningkatkan bagi hasil yang akan diterima oleh nasabah deposan (Rizky, 2011).

Gambar 1. Perkembangan Capital Adequacy Ratio Tahun 2011 - 2015 


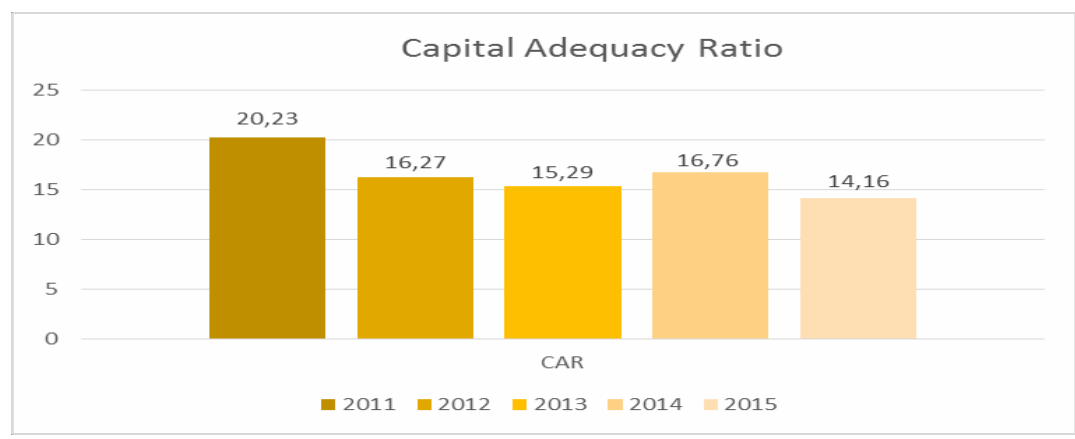

Sumber data : Statistik Perbankan Syariah Bank Indonesia

Pada gambar 1 menunjukkan bahwa, Capital Adequacy Ratio setiap tahunnya mengalami kondisi yang fluktuatif. Terlihat dari tahun 2011 jumlahnya sebesar 20,23 persen yang merupakan tingkat Capital Adequacy Ratio tertinggi dibandingkan tahun 2015 yang mencapai 14,16 persen. Capital Adequacy Ratio digunakan untuk pengukuran kinerja ini karena semakin besar rasio CAR maka menunjukkan indikasi bank dinilai masih dalam batas aman dalam operasinya. Keadaan permodalan yang memadai ini akan menjaga kepercayaan masyarakat untuk tetap menyimpan dananya di bank, oleh karena itu semakin besar pula bagi hasil yang diterima oleh nasabah. Apabila nilai CAR tinggi, maka berpengaruh baik pada tingkat bagi hasil deposito mudharabah yang diterima nasabah.

Rasio efisiensi diwakili dengan Biaya Operasional terhadap Pendapatan Operasional (BOPO) yaitu rasio yang digunakan untuk mengukur perbandingan biaya operasional atau biaya intermediasi terhadap pendapatan operasi yang diperoleh bank. Semakin kecil angka rasionya, maka semakin baik kondisi bank tersebut. BOPO digunakan untuk pengukuran kinerja ini karena semakin rendah BOPO maka bank semakin efisiensi dalam mengeluarkan biaya dalam bentuk pemberian investasi pembiayaan dalam rangka menghasilkan output (pendapatan) yang paling tinggi. Apabila BOPO menurun maka pendapatan bank meningkat. Dengan adanya peningkatan pendapatan bank maka tingkat bagi hasil yang diterima oleh nasabah juga meningkat (Gundari, 2015). Dengan demikian dapat dikatakan bahwa semakin rendah BOPO maka semakin tinggi tingkat bagi hasil deposito mudharabah yang diterima oleh para nasabah dan investor.

Gambar 2. Perkembangan Biaya Operasional terhadap Pendapatan Operasional Tahun $2011-2015$ 


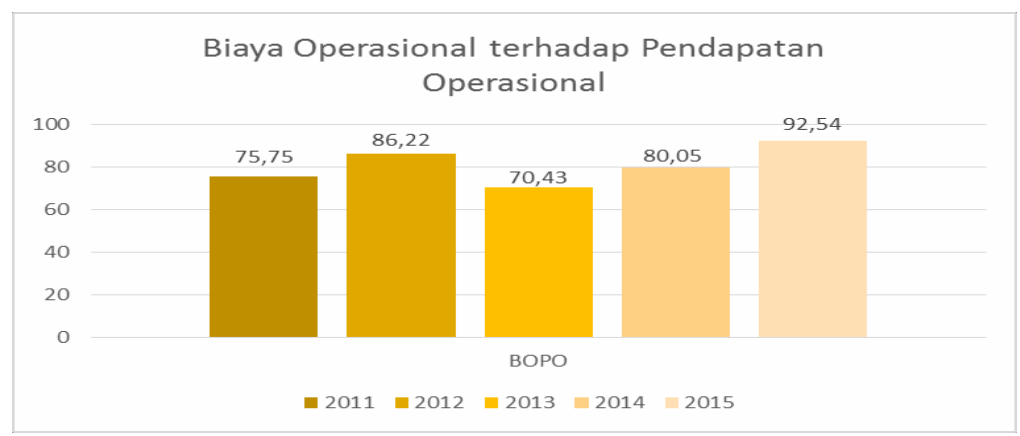

Sumber data : Statistik Perbankan Syariah Bank Indonesia

Pada gambar 2 menunjukkan bahwa, Biaya Operasional terhadap Pendapatan Operasional setiap tahunnya mengalami kondisi yang fluktuatif. Terlihat dari tahun 2011 jumlahnya sebesar 75,75 persen dan tertinggi pada tahun 2015 yang mencapai 92,54 persen, sedangkan nilai BOPO terendah terjadi pada tahun 2013 sebesar 70,43 persen.

Dari hasil penelitian yang dilakukan oleh Andryani (2012) dan Nana Nofianti (2015) menunjukkan bahwa BOPO berpengaruh positif terhadap tingkat bagi hasil deposito mudharabah. Hasil penelitian mengenai BOPO menunjukkan hasil yang berbeda, Juwariyah (2008) menunjukkan bahwa BOPO berpengaruh signifikan terhadap tingkat bagi hasil deposito mudharabah, sedangkan penelitian Siti Rahayu (2013) dan Agus Farianto (2014) menunjukkan bahwa BOPO secara parsial tidak berpengaruh signifikan terhadap tingkat bagi hasil deposito mudharabah.

\section{TELAAH TEORITIS}

\subsection{KINERJA KEUANGAN}

Menurut Fahmi (2012), kinerja keuangan merupakan gambaran dari pencapaian keberhasilan perusahaan dapat diartikan sebagai hasil yang telah dicapai atas berbagai aktivitas yang dilakukan. Dapat dijelaskan bahwa kinerja keuangan adalah suatu analisis yang dilakukan untuk melihat sejauh mana suatu perusahaan telah melaksanakan dengan menggunakan aturanaturan pelaksanaan keuangan secara baik dan benar. Sementara itu menurut Sucipto (2003), pengertian kinerja keuangan yakni penentuan ukuran-ukuran tertentu yang dapat mengukur keberhasilan suatu organisasi atau perusahaan dalam menghasilkan laba.

Perhitungan kinerja keuangan bank syariah menurut Peraturan Bank Indonesia No. 9/1/PBI/2007 Tentang Sistem Penilaian Tingkat Kesehatan Bank Umum Berdasarkan Prinsip Syariah, adalah sebagai berikut:

1. Rasio Permodalan (Capital)

Rasio permodalan ini berfungsi untuk mengukur kemampuan bank dalam menyerap kerugian-kerugian yang tidak dapat dihindari lagi serta dapat 
pula digunakan untuk mengukur besar-kecilnya kekayaan bank tersebut atau kekayaan yang dimiliki oleh para pemegang sahamnya. Dalam penelitian ini, rasio permodalan adalah Capital Adequacy Ratio (CAR).

Capital Adequacy Ratio (CAR) adalah rasio kinerja bank untuk mengukur kecukupan modal yang dimiliki bank dalam mempertahankan modal dan mengontrol resiko-resiko yang timbul yang dapat berpengaruh terhadap besarnya modal. Karena modal adalah salah satu faktor penting dalam suatu unit bisnis bank.

CAR merupakan indikator terhadap kemampuan bank untuk menutupi penurunan aktivanya sebagai akibat dari kerugian- kerugian bank yang disebabkan oleh aktiva yang berisiko (Lukman, 2009).

Semakin tinggi nilai CAR (sesuai ketentuan BI 8\%) maka semakin baik pula kinerja keuangan, namun jika nilai CAR rendah dibawah $8 \%$ maka kinerja keuangan buruk.

\section{Rasio Kualitas Aktiva Produktif (KAP)}

Rasio ini digunakan untuk mengetahui kualitas aktiva produktif, yaitu penanaman dana bank dalam rupiah atau valuta asing dalam bentuk kredit, surat berharga, penempatan pada bank lain dan penyertaan. Penilaian tersebut dilakukan untuk melihat apakah aktiva produktif digunakan untuk menghasikan laba secara maksimal. Selain itu penilaian kualitas aset dimaksudkan untuk menilai kondisi aset bank, termasuk antisipasi atas risiko gagal bayar dari pembiayaan (credit risk) yang akan muncul.

\section{Rasio Profitabilitas}

Analisis rasio profitabilitas bank adalah alat untuk menganalisis atau mengukur kemampuan bank dalam mendapatkan keuntungan yang dicapai oleh bank yang bersangkutan. Rasio profitabilitas yang digunakan dalam penelitian ini adalah Return on Asset (ROA).

Return On Asset (ROA) yaitu rasio yang digunakan untuk mengukur kemampuan manajemen bank dalam memperoleh keuntungan (laba) secara keseluruhan. Semakin besar ROA suatu bank, semakin besar pula tingkat keuntungan yang dicapai bank tersebut dan semakin baik pula posisi bank tersebut dari segi penggunaan aset (Lukman, 2009).

Menurut Kasmir (2008), rasio ini mengukur kemampuan perusahaan dalam memanfaatkan aktiva untuk memperoleh laba. Selain itu, rasio ini juga digunakan untuk mengukur tingkat pengembalian investasi yang telah dilakukan perusahaan dengan menggunakan seluruh dana (aktiva yang dimiliki). Rasio ini menunjukkan beberapa besar laba bersih yang diperoleh perusahaan bila diukur dengan nilai aktiva.

4. Rasio Efisiensi (Rasio Biaya Operasional) 
Rasio biaya operasional adalah perbandingan antara biaya operasional dan pendapatan operasional. Biaya Operasional terhadap Pendapatan Operasional (BOPO) merupakan rasio yang sering disebut rasio efisiensi ini digunakan untuk mengukur kemampuan manajemen bank dalam mengendalikan biaya operasional terhadap pendapatan operasional (Andriyani, 2012). Naik turunnya rasio ini akan mempengaruhi laba yang dihasilkan karena semakin besar rasio biaya operasional ini, maka akan menurunkan laba yang dihasilkan oleh bank, begitu juga sebaliknya.

Semakin tinggi nilai BOPO maka kinerja keuangannya akan semakin buruk, namun semakin rendah nilai BOPO maka akan semakin baik untuk kinerja keuangan.

\section{Rasio Likuiditas (Liquidity)}

Suatu bank dikatakan likuid apabila bank bersangkutan dapat memenuhi kewajiban hutang-hutangnya, dapat membayar kembali semua depositonya, serta dapat memenuhi permintaan kredit yang diajukan tanpa terjadi penangguhan. Rasio likuiditas ini dilakukan untuk menganalisis kemampuan bank dalam memenuhi kewajiban-kewajiban tersebut.

\subsection{DEPOSITO MUDHARABAH}

Menurut Ismail (2010), deposito mudharabah merupakan dana investasi yang ditempatkan oleh nasabah yang tidak bertentangan dengan prinsip syariah dan penarikannya hanya dapat dilakukan pada waktu tertentu, sesuai dengan akad perjanjian yang dilakukan antara bank dan nasabah investor. Deposito mudah diprediksi ketersediaan dananya karena terdapat jangka waktu dalam penempatannya. Sifat deposito yaitu penarikannya hanya dapat dilakukan sesuai jangka waktunya, sehingga pada umumnya balas jasa yang berupa nisbah bagi hasil yang diberikan oleh bank untuk deposito lebih tinggi dibanding dengan tabungan mudharabah.

Berdasarkan Fatwa DSN-MUI Nomor 3 Tahun 2000 menyatakan bahwa deposito yang dibenarkan dalam syariah adalah deposito yang berdasarkan prinsip mudharabah. Dalam transaksi deposito mudharabah, nasabah bertindak sebagai pemilik dana (shahibul maal) dan bank bertindak sebagai pengelola dana (mudharib). Adapun ketentuannya adalah sebagai berikut :

1. Dalam transaksi ini nasabah bertindak sebagai shahibul maal atau pemilik dana, dan bank bertindak sebagai mudharib atau pengelola dana.

2. Dalam kapasitasnya sebagai mudharib, bank dapat melakukan berbagai macam usaha yang tidak bertentangan dengan prinsip syariah dan mengembannya, termasuk didalamnya mudharabah dengan lain pihak.

3. Modal harus dinyatakan dengan jumlahnya, dalam bentuk tunai dan bukan piutang. 
4. Pembagian keuntungan dinyatakan dalam bentuk nisbah dan dituangkan dalam akad pembukaan rekening.

5. Bank sebagai mudharib menutup biaya operasional deposito dengan menggunakan nisbah keuntungan yang menjadi haknya

\subsection{TINGKAT BAGI HASIL MUDHABARABAH}

Menurut Agustianto (2005), bagi hasil adalah keuntungan atau hasil yang diperoleh dari pengelolaan dana baik investasi maupun transaksi jual beli yang diberikan nasabah. Adapun ketentuan prinsip bagi hasil terdiri atas (Wiroso,2005) :

1. Penentuan besarnya resiko bagi hasil dibuat pada waktu akad dengan berpedoman pada kemungkinan untung rugi.

2. Besarnya nisbah bagi hasil berdasarkan pada jumlah keuntungan yang diperoleh.

3. Jumlah pembagian bagi hasil meningkat sesuai dengan peningkatan jumlah pendapatan.

4. Tidak ada yang meragukan keuntungan bagi hasil.

5. Bagi hasil tergantung kepada keuntungan proyek yang dijalankan. Jika proyek itu tidak mendapatkan keuntungan maka kerugian akan ditanggung bersama oleh kedua belah pihak.

Sebagai lembaga intermediasi keuangan, bank syariah akan mendapatkan bagi hasil dari dana yang ditempatkan pada mitranya (nisbah). Bank syariah perlu mempertimbangkan mekanisme perhitungan bagi hasil yang terdiri dari dua sistem (Tim Pengembangan Perbankan Syariah Institut Bankir Indonesia, 2001):

1. Profit Sharing, adalah perhitungan bagi hasil didasarkan kepada net dari total pendapatan setelah dikurangi biaya yang dikeluarkan untuk memperoleh pendapatan tersebut.

2. Revenue Sharing, adalah perhitungan bagi hasil didasarkan kepada total seluruh pendapatan yang diterima sebelum dikurangi dengan biaya-biaya yang telah dikeluarkan.

Prinsip perhitungan bagi hasil pendapatan sangat penting untuk ditentukan di awal dan untuk diketahui oleh kedua belah pihak yang akan melakukan kesepakatan kerja sama bisnis karena apabila hal ini tidak dilakukan, maka telah menjadi gharar, sehingga transaksi menjadi tidak sesuai dengan prinsip syariah (Rizal, 2009).

\subsection{BANK UMUM SYARIAH DI INDONESIA}

Bank syariah adalah suatu lembaga keuangan yang berfungsi sebagai perantara bagi pihak yang berkelebihan dana dengan pihak yang kekurangan dana untuk kegiatan usaha dan kegiatan lainnya sesuai dengan hukum Islam. 
Selain itu, bank syariah biasa disebut Islamic Banking atau Interest Fee Banking, yaitu suatu sistem perbankan dalam pelaksanaan operasional tidak menggunakan sistem bunga (riba), spekulasi (maisir) dan ketidakpastian atau ketidakjelasan (gharar). Bank syariah sebagai sebuah lembaga keuangan mempunyai mekanisme dasar, yaitu menerima deposito dari pemilik modal (depositor) dan mempunyai kewajiban (liability) untuk menawarkan pembiayaan kepada investor pada sisi asetnya, dengan pola dan/atau skema pembiayaan yang sesuai dengan syariat Islam (Ali, 2008).

Bank umum pertama yang menggunakan sistem syariah di Indonesia yaitu PT Bank Muamalat Indonesia (BMI) yang mulai beroperasi pada 1992. Perkembangan bisnis bank syariah berlangsung lambat, sampai dengan lima tahun kedepan belum ada pertambahan bank baru. BMI masih menjadi satusatunya bank syariah. Baru pada 1998 pasar bank syariah mulai diramaikan dengan hadirnya PT. Bank Syariah Mandiri (BSM) anak perusahaan Bank Mandiri, bank BUMN terbesar di Indonesia. Selanjutnya menyusul kemunculan PT. Bank Mega Syariah pada 2001. Memasuki tahun 2009 ini ada dua bank baru memasuki pasar perbankan syariah yaitu PT. Bank Bukopin Syariah dan PT. BRI Syariah (www.datacon.co.id).

Perkembangan bank syariah pada jumlah bank mengalami peningkatan selama periode penelitian. Pada tahun 2009 terdapat 5 jumlah bank, terjadi peningkatan pada tahun 2010 sampai dengan 2014 menjadi 11 jumlah bank. Kemudian mengalami peningkatan kembali pada bulan Juni 2015 yaitu terdapat 12 jumlah bank. Perkembangan bank syariah pada jumlah kantor juga mengalami peningkatan selama periode penelitian. Pada tahun 2009 terus mengalami peningkatan hingga mencapai nilai tertinggi pada tahun 2014 sebesar 2.149 jumlah kantor pada bank syariah.

Menurut Halim (2015), Selaku regulator, Bank Indonesia memberikan perhatian yang serius dan bersungguh-sungguh dalam mendorong perkembangan perbankan syariah. Semangat ini dilandasi oleh keyakinan bahwa perbankan syariah akan membawa 'maslahat' bagi peningkatan ekonomi dan pemerataan kesejahteraan masyarakat. Pertama, bank syariah lebih dekat dengan sektor riil karena produk yang ditawarkan, khususnya dalam pembiayaan, senantiasa menggunakan underlying transaksi di sektor riil sehingga dampaknya lebih nyata dalam mendorong pertumbuhan ekonomi. Kedua, tidak terdapat produk-produk yang bersifat spekulatif (gharar) sehingga mempunyai daya tahan yang kuat dan teruji ketangguhannya dari direct hit krisis keuangan global. Secara makro, perbankan syariah dapat memberikan daya dukung terhadap terciptanya stabilitas sistem keuangan dan perekonomian nasional. Ketiga, sistem bagi hasil (profit-loss sharing) yang menjadi ruh perbankan syariah akan membawa manfaat yang lebih adil bagi semua pihak, baik bagi pemilik dana selaku deposan, pengusaha selaku debitur maupun pihak bank selaku pengelola dana. 


\subsection{PERUMUSAN HIPOTESIS PENELITIAN}

a. Ho : Variabel Return On Asset (ROA), Capital Adequacy Ratio (CAR) dan Biaya Operasional terhadap Pendapatan Operasional (BOPO) tidak berpengaruh secara parsial terhadap tingkat bagi hasil deposito mudharabah pada Bank Umum Syariah di Indonesia.

Ha : Variabel Return On Asset (ROA), Capital Adequacy Ratio (CAR) dan Biaya Operasional terhadap Pendapatan Operasional (BOPO) berpengaruh secara parsial terhadap tingkat bagi hasil deposito mudharabah pada Bank Umum Syariah di Indonesia.

b. Ho : Variabel Return On Asset (ROA), Capital Adequacy Ratio (CAR) dan Biaya Operasional terhadap Pendapatan Operasional (BOPO) tidak berpengaruh secara simultan terhadap tingkat bagi hasil deposito mudharabah pada Bank Umum Syariah di Indonesia.

$H_{a}$ : Variabel Return On Asset (ROA), Capital Adequacy Ratio (CAR) dan Biaya Operasional terhadap Pendapatan Operasional (BOPO) berpengaruh secara simultan terhadap tingkat bagi hasil deposito mudharabah pada Bank Umum Syariah di Indonesia.

\section{METODOLOGI PENELITIAN}

Populasi dalam penelitian ini adalah Bank Umum Syariah yang berada di Indonesia selama periode Januari 2011 - Juni 2015. Bank Umum Syariah menurut Otoritas Jasa Keuangan (OJK) adalah bank yang secara penuh bertransaksi secara syariah dan bukan merupakan unit usaha syariah. Saat ini, jumlah Bank Umum Syariah (BUS) yang beroperasi di Indonesia sebanyak dua belas bank. Di bawah ini merupakan tabel yang menampilkan daftar Bank Umum Syariah (BUS) di Indonesia.

Tabel 1. Data Bank Umum Syariah

\begin{tabular}{|c|c|c|}
\hline No. & Nama Perusahaan & Kode \\
\hline 1 & PT. Bank Muamalat Indonesia & BMI \\
\hline 2 & PT. Bank Victoria Syariah & BVS \\
\hline 3 & Bank BRIsyariah & BRIS \\
\hline 4 & B.P.D. Jawa Barat Banten Syariah & BJBS \\
\hline 5 & Bank BNI Syariah & BNIS \\
\hline 6 & Bank Syariah Mandiri & BSM \\
\hline 7 & Bank Syariah Mega Indonesia & BSMI \\
\hline 8 & Bank Panin Syariah & BPS \\
\hline 9 & PT. Bank Bukopin Syariah & BBS \\
\hline
\end{tabular}




\begin{tabular}{ccc}
\hline 10 & PT. BCA Syariah & BCAS \\
\hline 11 & PT. Maybank Syariah Indonesia & MIS \\
\hline 12 & PT. Bank Tabungan Nasional Syariah & BTNS \\
\hline
\end{tabular}

Sumber data : Statistik Perbankan Syariah Bank Indonesia Tahun 2015

Sampel adalah bagian dari jumlah dan karakteristik yang dimiliki oleh populasi tersebut (Sugiyono, 2009). Metode penentuan sampel yang digunakan dalam penelitian ini adalah purposive sampling. Menurut Siregar (2011), purposive sampling adalah teknik pemilihan sampel berdasarkan pada kriteria-kriteria tertentu. Kriteria tersebut adalah Bank Umum Syariah yang mengungkapkan laporan Islamic Social Reporting (ISR) dalam annual report selama tahun pengamatan dalam laporan keuangan.

Kriteria pengambilan sampel yaitu, Bank Umum Syariah yang terdata di Bank Indonesia pada tahun 2015 dan memiliki laporan tiap tahunnya. Berdasarkan kriteria tersebut, maka diperoleh 12 (dua belas) unit Bank Umum Syariah. Karena semua bank yang terdaftar sebagai Bank Umum Syariah mengungkapkan laporan Islamic Social Reporting (ISR) dalam annual report perusahaan. Jumlah sampel yang memenuhi kriteria 12 dikali 4 tahun sehingga jumlah sampel sebanyak 48.

Data yang digunakan penelitian ini merupakan data sekunder, data tersebut diperoleh langsung dari Laporan situs resmi Bank Indonesia seperti Laporan Bulanan Bank Indonesia tentang Statistik Perbankan Syariah. Metode yang digunakan dalam pengumpulan data untuk melakukan penelitian ini adalah field research, library research, dan internet research. Penelitian ini menggunakan metode analisis regresi linier berganda dengan menggunakan program komputer yaitu Software Statistical Package for the Social Sciences (SPSS) versi 20.0 dan Microsoft Excel 2007. Metode yang digunakan dalam menganalisis data pada penelitian ini adalah Uji Asumsi Klasik dan Uji Hipotesis. Uji Asumsi klasik dilakukan untuk mendeteksi apakah terdapat normalitas, multikolinieritas, heterokedastisitas dan autokorelasi. Sedangkan Uji Hipotesis dalam pengujian ini menggunakan Uji Statistik meliputi Uji t, Uji F dan Uji Koefisien Determinasi (Adjusted $R$ Square).

Operasional variabel merupakan spesifikasi kegiatan peneliti dalam mengukur suatu variabel. Spesifikasi tersebut menunjukkan pada dimensidimensi dan indikator-indikator dari variabel peneliti yang diperoleh melalui pengamatan dan penelitian terdahulu.

1. Variabel Dependen (Y)

Deposito Mudharabah adalah dana investasi yang sifatnya sesuai dengan syari'at Islam dari nasabah yang penarikannya dapat dilakukan pada waktu tertentu sesuai dengan kesepakatan. Pemilik rekening disebut deposan yang berasal dari peorangan atau badan. Data operasional yang digunakan dalam penelitian ini diperoleh dari Bank Indonesia yaitu Statistika Perbankan Syariah berdasarkan perhitungan dari Januari 2011 sampai dengan Juni 2015 dalam miliar rupiah. 
1. Variabel Independen (X)

Dalam penelitian ini menggunakan tiga variabel independen antara lain sebagai berikut :

a. Return On Asset $\left(\mathrm{X}_{1}\right)$ adalah salah satu rasio yang digunakan untuk mengukur kemampuan manajemen bank dalam memperoleh keuntungan (laba) secara keseluruhan. Data operasionalnya yang digunakan dalam penelitian ini diperoleh dari Bank Indonesia yaitu Statistika Perbankan Syariah berdasarkan perhitungan bulanan, yaitu dari Januari 2011 - Juni 2015 yang dinyatakan dalam bentuk persentase. Rumus Return On Asset (ROA) adalah sebagi berikut:

$$
\text { ROA }=\frac{\text { Laba bersih }}{\text { Total aset }} \times 100 \%
$$

b. Capital Adequacy Ratio $\left(\mathrm{X}_{2}\right)$ adalah rasio yang memperlihatkan seberapa jauh seluruh aktiva bank yang mengandung risiko (kredit, penyertaan, surat berharga, tagihan pada bank lain) ikut dibiayai dari dana modal sendiri bank disamping memperoleh dana-dana dari sumber-sumber diluar bank, seperti dana masyarakat, pinjaman (utang) dan lain-lain. Data operasional yang digunakan dalam penelitian ini diperoleh dari Bank Indonesia yaitu Statistika Perbankan Syariah berdasarkan perhitungan bulanan dari Januari 2011 sampai dengan Juni 2015 dalam bentuk persentase. Rumus Capital Adequacy Ratio (CAR) adalah sebagai berikut:

$$
\text { CAR }=\frac{\text { Modal bank }}{\text { Aset Tertimbang Menurut Risiko }} \times 100 \%
$$

c. Biaya Operasional terhadap Pendapatan Operasional $\left(\mathrm{X}_{3}\right)$ merupakan rasio efisiensi bank yang mengukur beban operasional terhadap pendapatan operasional. Semakin tinggi nilai BOPO maka akan semakin tinggi efisien operasi bank. Data operasional yang digunakan dalam penelitian ini diperoleh dari Bank Indonesia yaitu Statistika Perbankan Syariah berdasarkan perhitungan bulanan, yaitu dari Januari 2011 - Juni 2015 yang dinyatakan dalam bentuk persentase. Rumus untuk perhitungan Biaya Operasional terhadap Pendapatan Operasional (BOPO) adalah sebagai berikut :

$$
\text { BOPO }=\frac{\text { Biaya }(\text { beban }) \text { Operasional }}{\text { Pendapatan Operasional }} \times 100 \%
$$

\section{PEMBAHASAN}

Penelitian ini dilakukan pada Perbankan Syariah yang ada di Indonesia. Data yang digunakan dalam penelitian ini adalah data sekunder. Data tersebut berupa laporan keuangan tahunan Bank Umum Syariah untuk periode 
Januari 2011 - Juni 2015. Bank Umum Syariah (BUS) yang terdaftar di Bank Indonesia sampai dengan tahun 2015 sebanyak 12 (dua belas) bank.

Variabel yang digunakan dalam penelitian ini yang meliputi Return On Assets (ROA), Capital Adequacy Ratio (CAR), Biaya Operasional terhadap Pendapatan Operasional dan Deposito Mudharabah. Keseluruhan data variabel dalam penelitian ini diolah atau ditransformasikan ke dalam bentuk Ln (Logaritma Natural). Menurut Algifari (2013), untuk menstandarkan data yang dikarenakan data memiliki satuan yang berbeda agar menjadi sama, maka model kemudian ditransformasikan ke dalam bentuk persamaan logaritma natural (Ln) pada prinsipnya model ini merupakan hasil transformasi dari suatu model tidak linier menjadi model linier, dengan jalan membuat model dalam bentuk logaritma.

\subsection{HASIL UJI ASUMSI KLASIK}

\subsubsection{Hasil Uji Multikolonieritas}

Pengujian multikolonieritas dilakukan untuk menguji apakah pada model regresi ditemukan adanya korelasi antar variabel independen. Untuk mendeteksi adanya problem multiko, maka dapat dilakukan dengan melihat nilai Tolerance dan Variance Inflation Factor (VIF) serta besaran korelasi antar variabel independent. Nilai cut off yang umum dipakai untuk menunjukkan adanya multikolinieritas adalah nilai Tolerance $>0,10$ atau sama dengan VIF $<10$, maka model dinyatakan tidak terdapat gejala multikolinieritas.

Tabel 2. Uji Multikolinieritas

Coefficients ${ }^{\mathrm{a}}$

\begin{tabular}{llll}
\hline & Model & \multicolumn{2}{c}{ Collinearity Statistics } \\
\cline { 3 - 4 } & & Tolerance & VIF \\
\hline 1 & (Constant) & & 1,026 \\
\hline & Ln_ROA & 0,974 & 1,027 \\
\hline Ln_CAR & 0,974 & 1,013 \\
\hline & Ln_BOPO & 0,988 &
\end{tabular}

a. Dependent Variable: Ln_Deposito_Mudharabah

Berdasarkan output pada Coefficients dalam Tabel 2 di atas, terlihat bahwa nilai Tolerance menunjukkan terdapat ketiga variabel independen yang memiliki nilai Tolerance lebih dari 0,10, yaitu ROA dengan nilai 0,974, CAR dengan nilai 0,974 dan BOPO dengan nilai 0,988. Hasil dari perhitungan nilai Variance Inflation Factor (VIF) juga menunjukkan hal yang sama, yaitu ketiga variabel independen yang memiliki nilai VIF lebih kurang dari 10. Pada variabel ROA dengan nilai VIF sebesar 1,026, variabel CAR dengan nilai VIF sebesar 1,027 serta pada variabel BOPO dengan nilai VIF sebesar 1,013. Dengan demikian dapat disimpulkan bahwa tidak terjadi multikolinieritas. 


\subsubsection{Hasil Uji Normalitas}

Pengujian normalitas dilakukan untuk menguji apakah dalam sebuah model regresi, variabel dependen dan variabel independen atau keduanya mempunyai distribusi normal atau tidak. Model regresi yang baik adalah distribusi data normal atau mendekati normal. Berdasarkan hasil pengujian memperlihatkan penyebaran data yang berada disekitar garis diagonal dan mengikuti arah garis diagonal, ini menunjukkan bahwa model regresi memenuhi asumsi normalitas. Gambar 3 berikut ini hasil uji normalitas dengan menggunakan grafik PP Plot.

Gambar 3. Grafik PP-Plot

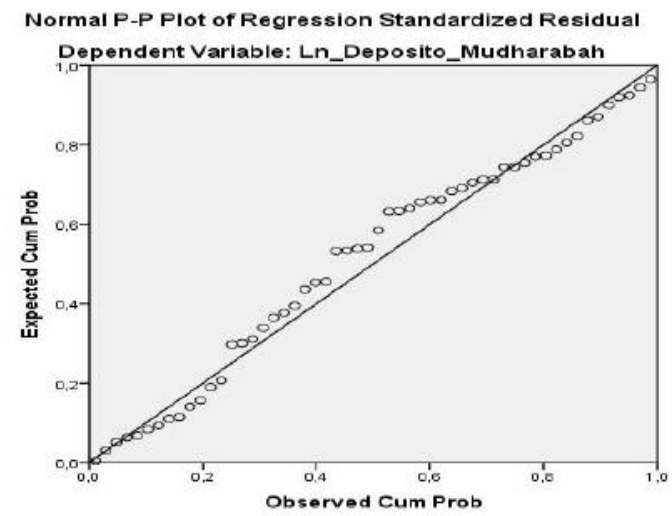

\subsubsection{Hasil Uji Heteroskedastisitas}

Pengujian heteroskedastisitas dilakukan untuk menguji apakah dalam sebuah model regresi, terjadi ketidaksamaan varians dari residual dari satu pengamatan ke pengamatan yang lain. Jika varians dari residual dari suatu pengamatan ke pengamatan yang lain tetap, maka disebut homoskedastisitas. Bedasarkan hasil pengujian menunjukkan titik-titik menyebar secara acak dan tidak membentuk pola tertentu serta tersebar diatas dan dibawah angka 0 (nol) pada sumbu Y. Ini berarti tidak terjadi heteroskedastisitas sehingga model regresi layak digunakan untuk memprediksi deposito mudharabah berdasarkan variabel yang mempengaruhinya, yaitu ROA, CAR dan BOPO. Gambar 4 berikut ini Hasil uji heteroskedastisitas dengan menggunakan grafik Scatterplot.

Gambar 4. Grafik Scatterplot 


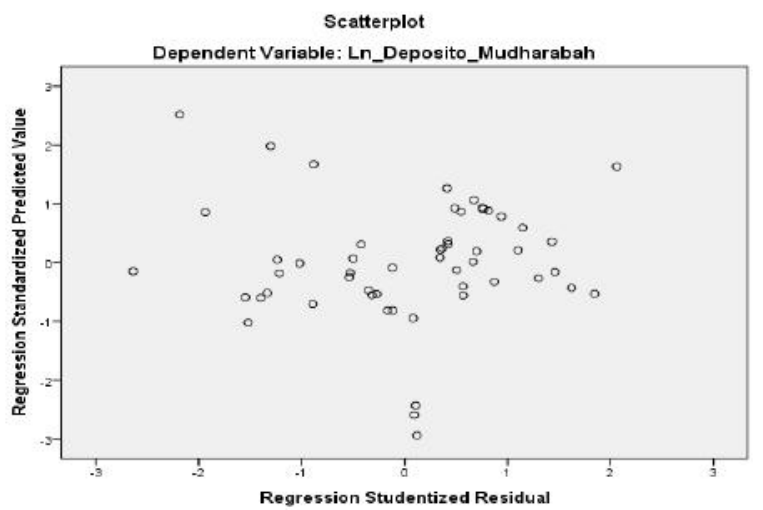

\subsubsection{Hasil uji autokorelasi}

Pengujian adanya autokorelasi dilakukan dengan melihat nilai Durbin Watson. Pengujian ini digunakan untuk mengetahui adanya kesalahan pengganggu pada periode $\mathrm{t}$ dengan kesalahan pengganggu pada periode $\mathrm{t}-1$ (sebelumnya).

Tabel 3. Uji Durbin-Watson

Model Summaryb

\begin{tabular}{ccrrrr} 
Model & R & R Square & $\begin{array}{c}\text { Adjusted R } \\
\text { Square }\end{array}$ & $\begin{array}{c}\text { Std. Error of } \\
\text { the Estimate }\end{array}$ & Durbin-Watson \\
\hline 1 & $0,711^{\mathrm{a}}$ & 0,506 & 0,476 & 0,24365 & 0,796 \\
\hline
\end{tabular}

a. Predictors: (Constant), Ln_BOPO, Ln_ROA, Ln_CAR

b. Dependent Variable:Ln_Deposito_Mudharabah

Berdasarkan Tabel 3 di atas, nilai Durbin-Watson sebesar 0,796. Jika dibandingkan dengan tabel Durbin-Watson dengan $(n)=54$ dan jumlah variabel independen $(\mathrm{k}=4)$ diperoleh nilai $\mathrm{dL}$ (lower) $=1,4069$ dan $\mathrm{dU}$ (upper $)=1,7234$, sehingga nilai 4-dU sebesar $4-1,7234=2,2766$ sedangkan nilai 4-dL sebesar $4-1,4069=2,5931$. Oleh karena itu, nilai DW $=0,796$ ini berada diantara -2 sampai dengan +2 dapat dikatakan bahwa sudah tidak ada lagi gejala autokorelasi pada persamaan model penelitian.

\subsection{HASIL UJI HIPOTESIS}

\subsubsection{Hasil Uji koefisien determinasi}

Berikut ini disajikan hasil uji koefisien determinasi untuk variabel Y, X1, X2 dan X3

Tabel 4. Uji Adjusted R Square $\left(\mathrm{R}^{2} \mathrm{adj}\right)$

Model Summary $b$ 


\begin{tabular}{lrrrrr}
\hline Model & R & R Square & $\begin{array}{l}\text { Adjusted R } \\
\text { Square }\end{array}$ & $\begin{array}{l}\text { Std. Error of } \\
\text { the Estimate }\end{array}$ & \multicolumn{1}{c}{$\begin{array}{l}\text { Durbin- } \\
\text { Watson }\end{array}$} \\
\hline 1 & $0,711^{\mathrm{a}}$ & 0,506 & 0,476 & 0,24365 & 0,796 \\
\hline
\end{tabular}

a. Predictors: (Constant), Ln_BOPO, Ln_ROA, Ln_CAR

b. Dependent Variable: Ln_Deposito_Mudharabah

Berdasarkan hasil Tabel 4 di atas, $\mathrm{R}$ menunjukkan nilai korelasi atau hubungan antara variabel bebas dan variabel terikatnya. Nilai R sebesar 0,711 atau $71,1 \%$ menyatakan bahwa terdapat hubungan yang kuat antara $\mathrm{X} 1$ (ROA), X2 (CAR) dan X3 (BOPO) secara bersama-sama terhadap variabel Y (Tingkat Bagi Hasil Deposito Mudharabah).

Nilai $R$ Square menunjukkan besarnya pengaruh antara variabel bebas terhadap variabel terikatnya. Nilai $R$ Square sebesar 0,506 atau 50,6\% menyatakan terdapat pengaruh sebesar 50,6\% antara X1 (ROA), X2 (CAR) dan X3 (BOPO) secara bersama-sama terhadap variabel Y (Tingkat Bagi Hasil Deposito Mudharabah). Sementara sisanya 49,4\% dipengaruhi oleh faktor lain di luar model.

Besarnya angka Adjusted $R$ Square adalah 0,476 atau sebesar 47,6\%. Dapat disimpulkan bahwa pengaruh Return On Asset (ROA), Capital Adequacy Ratio (CAR), dan Biaya Operasional terhadap Pendapatan Operasional (BOPO) adalah 47,6\%. Sedangkan sisanya sebesar 52,4\% $(100 \%$ - 47,6\%) dipengaruhi oleh variabel-variabel lain yang tidak dimasukkan ke dalam penelitian ini misalnya seperti Return On Equity (ROE), Non Performing Finance (NPF) dan Financing Debt to Ratio (FDR). Adapun angka koefisien korelasi (R) menunjukkan nilai sebesar 0,711 yang menandakan bahwa hubungan antara variabel bebas dan variabel terikat adalah kuat karena memiliki nilai lebih dari 0,5 $(\mathrm{R}>0,5)$ atau $0,711>0,5$.

\subsubsection{Hasil Uji Signifikansi Simultan (Uji Statistik F)}

Tabel 5 berikut ini disajikan hasil uji statistik F untuk variabel Y, X1,X2 dan X3.

Tabel 5.Uji Statistik F (Simultan)

ANOVA $^{\mathrm{a}}$

\begin{tabular}{crrrrr}
\hline Model & $\begin{array}{l}\text { Sum of } \\
\text { Squares }\end{array}$ & Df & Mean Square & F & \multicolumn{1}{c}{ Sig. } \\
\hline 1 Regression & 3,038 & 3 & 1,013 & 17,058 & $0,000^{\mathrm{b}}$ \\
\hline Residual & 2,968 & 50 & 0,059 & & \\
\hline Total & 6,006 & 53 & & & \\
\hline
\end{tabular}

a. Dependent Variable: Ln_Deposito_Mudharabah

b. Predictors: (Constant), Ln_BOPO, Ln_ROA, Ln_CAR 
Berdasarkan tabel 5 di atas, nilai F-hitung sebesar 17,058 dengan nilai Ftabel df: $\alpha,(\mathrm{k}-1),(\mathrm{n}-\mathrm{k})$ atau 0,05, (4-1), (54-4) = 2,79 dan nilai signifikansi 0,000. Jadi kesimpulannya adalah karena nilai Fhitung > Ftabel (17,058 > 2,79) dan nilai signifikansi lebih kecil dari $0,05(0,000<0,05)$ maka $\mathrm{H}_{0}$ ditolak atau $\mathrm{Ha}$ diterima, sehingga hipotesis yang menyatakan tidak ada pengaruh antara ROA, CAR dan BOPO (secara bersama-sama) terhadap tingkat bagi hasil deposito mudharabah ditolak. Dengan demikian terbukti bahwa terdapat pengaruh antara ROA, CAR dan BOPO secara simultan terhadap tingkat bagi hasil deposito mudharabah.

\subsubsection{Uji Signifikansi Parameter Individual (Uji t Statistik)}

Tabel 6 menunjukkan bahwa hasil uji statistik t untuk variabel $\mathrm{Y}, \mathrm{X} 1, \mathrm{X} 2$, dan X3, sebagai berikut:

Tabel 6.Uji Statistik t (Parsial)

Coefficients $^{\mathrm{a}}$

\begin{tabular}{|c|c|c|c|c|c|c|c|}
\hline \multirow[t]{2}{*}{ Model } & \multicolumn{2}{|c|}{$\begin{array}{c}\text { Unstandardize } \\
\text { Coefficients }\end{array}$} & $\begin{array}{c}\text { Standar } \\
\text { dized } \\
\text { Coeffici }\end{array}$ & \multirow[t]{2}{*}{$\mathrm{t}$} & \multirow[t]{2}{*}{ Sig. } & \multicolumn{2}{|c|}{$\begin{array}{c}\text { Collinearity } \\
\text { Statistics }\end{array}$} \\
\hline & B & Std. Error & Beta & & & Toleranc & VIF \\
\hline 1 (Constant) & $\begin{array}{r}17,58 \\
5 \\
\end{array}$ & 1,077 & & 16,333 & 0,000 & & \\
\hline Ln_ROA & $-0,273$ & 0,055 & $-0,500$ & $-4,965$ & 0,000 & 0,974 & 1,026 \\
\hline Ln_CAR & $-2,122$ & 0,378 & $-0,566$ & $-5,620$ & 0,000 & 0,974 & 1,027 \\
\hline $\begin{array}{l}\text { Ln_BOP } \\
\mathrm{O}\end{array}$ & $-0,072$ & 0,053 & $-0,135$ & $-1,345$ & 0,185 & 0,988 & 1,013 \\
\hline
\end{tabular}

a. Dependent Variable:Ln_Deposito_Mudharabah

Berdasarkan pada Tabel 6 di atas, variabel ROA mempunyai nilai signifikansi $0,000<0,05$. Hal ini berarti menerima $\mathrm{H}_{\mathrm{a}}$ atau menolak $\mathrm{H}_{0}$ sehingga dapat disimpulkan bahwa variabel ROA secara parsial berpengaruh terhadap tingkat bagi hasil deposito mudharabah. Hasil penelitian ini mendukung hasil penelitian yang dilakukan oleh Juwariyah (2008) dan Isna (2012) bahwa ROA berpengaruh signifikan terhadap tingkat bagi hasil deposito mudharabah. Apabila ROA meningkat maka pendapatan juga akan meningkat. Dengan adanya peningkatan pendapatan maka tingkat bagi hasil yang diterima oleh nasabah juga akan meningkat.

Variabel CAR mempunyai nilai signifikansi $0,000<0,05$. Hal ini berarti menerima $\mathrm{Ha}_{\mathrm{a}}$ atau menolak $\mathrm{H} 0$ sehingga dapat disimpulkan bahwa variabel CAR secara parsial berpengaruh terhadap tingkat bagi hasil deposito mudharabah. Hasil penelitian ini mendukung hasil penelitian yang dilakukan oleh Rizky Amelia (2011) yang menyatakan bahwa CAR berpengaruh signifikan positif terhadap tingkat bagi hasil deposito mudharabah. Semakin besar CAR maka menunjukkan indikasi bank dinilai masih dalam batas aman dalam operasinya. Keadaan permodalan yang memadai ini akan menjaga 
kepercayaan masyarakat untuk tetap menyimpan dananya di bank, oleh karena itu semakin besar pula tingkat bagi hasil deposito mudharabah yang diterima oleh nasabah (Gundari, $2015: 6$ ).

Variabel BOPO mempunyai nilai signifikansi 0,185 > 0,05. Hal ini berarti menerima $\mathrm{H}_{0}$ atau menolak $\mathrm{H}_{\mathrm{a}}$ sehingga dapat disimpulkan bahwa variabel BOPO secara parsial berpengaruh terhadap tingkat bagi hasil deposito mudharabah. Hasil penelitian ini konsisten dengan hasil penelitian yang dilakukan oleh Sudiyatno dan Jati (2010), Khairiah dan Kunti (2012), dan Pramilu (2012), yang menyatakan bahwa tidak ada pengaruh antara biaya operasional terhadap pendapatan operasional dengan tingkat bagi hasil deposito mudharabah. Hal ini dikarenakan jika bank syariah memperoleh pendapatan operasional yang kecil maka resiko yang dimiliki bank syariah akan ditanggung oleh nasabah.

Apabila BOPO menurun maka pendapatan bank meningkat. Dengan adanya peningkatan pendapatan bank tingkat bagi hasil deposito mudharabah yang diterima oleh nasabah juga meningkat. Hal ini bukan disebabkan bank tidak dapat mengefisienkan biayanya, namun disebabkan tahun-tahun pertama pasca krisis 2008, tingkat suku bunga bank konvensional yang relatif tinggi menjadi dasar pertimbangan beberapa bank syariah dalam menjaga dana pihak ketiganya dengan memberikan subsidi porsi bagi hasil yang besar kepada nasabah deposito mudharabah (Andarini, 2013).

Diantara variabel ROA, CAR dan BOPO, variabel ROA yang paling dominan terhadap tingkat bagi hasil deposito mudharabah. Dilihat dari tabel unstandardized coefficients dengan nilai $\beta$ sebesar $-0,273$ dan tingkat signifikansi lebih kecil dari $0,05(0,000<0,05)$. Semakin besar tingkat keuntungan (ROA) yang didapat oleh bank, maka semakin besar pula upaya manajemen menginvestasikan keuntungan tersebut dengan berbagai kegiatan yang menguntungkan manajemen, terutama dengan deposito mudharabah. Selain itu semakin besar suatu bank menghasilkan laba maka tingkat bagi hasil yang diberikan bank syariah besar berarti bank sudah efektif dalam mengelola asetnya (Pratami, 2011).

\section{KESIMPULAN}

Return On Asset (ROA) secara parsial berpengaruh secara signifikan terhadap Tingkat Bagi Hasil Deopsito Mudharabah pada Bank Umum Syariah di Indonesia, begitu pula Capital Adequacy Ratio (CAR) secara parsial berpengaruh secara signifikan terhadap Tingkat Bagi Hasil Deopsito Mudharabah pada Bank Umum Syariah di Indonesia, Sedangkan Biaya Operasional terhadap Pendapatan Operasional (BOPO) secara parsial tidak berpengaruh terhadap Tingkat Bagi Hasil Deposito Mudharabah pada Bank Umum Syariah di Indonesia.

Return On Asset (ROA), Capital Adequacy Ratio (CAR) dan Biaya Operasional terhadap Pendapatan Operasional (BOPO) secara simultan 
mempunyai pengaruh yang signifikan terhadap Tingkat Bagi Hasil Deopsito Mudharabah pada Bank Umum Syariah di Indonesia.

Variabel yang paling dominan terhadap Tingkat Bagi Hasil Deposito Mudharabah adalah variabel Return On Asset (ROA).

Tidak berpengaruhnya BOPO terhadap tingkat Bagi Hasil, karena jika biaya operasional bank meningkat maka pendapatan bank akan menurun, dengan pendapatan operasional yang kecil maka resiko yang dimiliki bank syariah akan ditanggung oleh nasabah (nasabah akan mendapatkan bagi hasil deposito mudharabah yang kecil). Apabila biaya operasional bank menurun maka pendapatan bank akan meningkat. Dengan adanya peningkatan pendapatan bank, maka tingkat bagi hasil deposito mudharabah yang diterima oleh nasabah juga meningkat.

ROA dan CAR merupakan ukuran keberhasilan kinerja keuangan bank syariah yang memiliki pengaruh signifikan terhadap tingkat bagi hasil deposito mudharabah. Apabila ROA dan CAR meningkat maka bagi hasil yang diterima nasabah akan meningkat, maka dari itu diharapkan kepada seluruh Bank Umum syariah di Indonesia untuk terus dapat meningkatkan kinerja keuangannya, supaya tingkat bagi hasil deposito mudharabah yang diberikan kepada nasabah menjadi lebih besar, dengan demikia para deposan akan terus menyimpan dananya di Bank syariah yang memiliki tawaran imbal hasil yang lebih besar dan bebas dari riba (bunga).

\section{DAFTAR PUSTAKA}

Algifari, 2013. Analisis Regresi : Teori, Kasus dan Solusi. Edisi Kedua. Yogyakarta : BPFE-Yogyakarta.

Amelia, Rizky. 2011. "Pengaruh CAR, FDR dan NPF Terhadap Return Bagi Hasil Deposito Mudharabah Pada Perbankan Syariah”. Skripsi S1 Fakultas Syariah dan Hukum Syarif Hidayatullah Jakarta.

Apriandika, Rangga. 2011. "Analisis Hubungan Kinerja Keuangan Terhadap Tingkat Bagi Hasil Simpanan Mudharabah Pada Bank Syariah”. Jurnal. Universitas Lampung.

Fahmi, Irham. 2012. Analisis Laporan Keuangan. Cetakan Kedua. Bandung : Alfabeta.

Fatwa DSN-MUI No. 03/DSN-MUI/IV/2000 Tentang Deposito.

Gundari, 2015. "Pengaruh Kinerja Keuangan Terhadap Tingkat Bagi Hasil Deposito Mudharabah Pada Bank Mega Syariah Indonesia Tahun 2004 - 2013”. Skripsi : Universitas Negeri Yogyakarta.

Ismail, 2010. Manajemen Perbankan dari Teori Menuju Aplikasi. Jakarta : Kencana.

Juwariyah, Siti. 2008. “Analisis Pengaruh Profitabilitas dan Efisiensi Terhadap Tingkat Bagi Hasil Tabungan dan Deposito Mudharabah 
Muthlaqah (Studi Pada Bank Muamalat Indonesia Tbk)”. Skripsi UIN Sunan Kalijaga, Yogyakarta : Dipublikasikan.

Kasmir. 2008. Bank dan Lembaga Keuangan Lainnya. Edisi Revisi 2.

Lukman, Dendawijaya. 2009. Manajemen Perbankan. Edisi Kedua Jakarta : Ghalia Indonesia.

Andriyani, 2012. "Analisis Pengaruh Return On Asset, BOPO dan Suku Bunga Terhadap Tingkat Bagi Hasil Deposito Mudharabah Pada Bank Umum Syariah”. Jurnal Ekonomi dan Bisnis, Volume 11, Nomor 01, hal.30.

Nofianti, Nana. 2015. “Analisis Pengaruh Return On Asset (ROA), Biaya Operasional terhadap Pendapatan Operasional (BOPO), Suku Bunga, Financing to Deposits Ratio (FDR) dan Non Performing Financing (NPF) Terhadap Tingkat Bagi Hasil Deposito Mudharabah (Studi Empiris pada Bank Umum Syariah di Indonesia Tahun 2011 - 2013)”. Jurnal Bisnis dan Manajemen, Volume 5, Nomor 1, hal.76.

Peraturan Bank Indonesia No.9/1/PBI/2007 Tentang Sistem Penilaian Tingkat Kesehatan

Bank Umum Berdasarkan Prinsip Syariah. Jakarta Undang-Undang No. 7 Tahun 1992 Tentang Perbankan.

Pratami, Wuri Arianti Novi. 2011. “Analisis Pengaruh Dana Pihak Ketiga (DPK), Capital Adequacy Ratio (CAR), Non Performing Financing (NPF) dan Return On Asset (ROA) terhadap pembiayaan pada perbankan syariah”. Skripsi. Universitas Diponegoro. Semarang

Rahayu, Siti. 2013. "Pengaruh Return On Asset, BOPO, Suku Bunga dan Capital Adequacy Ratio Terhadap Tingkat Bagi Hasil Deposito Mudharabah Pada Perbankan Syariah”. Jurnal Ekonomi dan Bisnis.

Siregar, Syofian. 2011. Statistika Deskriptif Untuk Penelitian. Jakarta : PT. Raja Grafindo Persada.

Sucipto, 2003. "Penilaian Kinerja Keuangan”. Sumatera : Jurnal Digital Library Universitas Sumatera Utara.

Sugiyono, 2009. Metode Penelitian Bisnis (Pendekatan Kuantitatif, Kualitatif, dan $R \& D)$. Bandung : Alfabeta.

Tim Pengembangan Perbankan Syariah Institut Bankir Indonesia, 2001. Konsep Produk dan Implementasi Operasional Bank Syariah. Jakarta : Djambatan.

Ulfah, Khasanah. 2012."Analisis pengaruh pendapatan bank, DPK, dan ROA terhadap profit sharing deposito mudharabah pada PT Bank Syariah Mandiri tahun 2008-2011 ". Skripsi IAIN Walisongo 
Undang-Undang No. Undang-Undang Nomor : 21 Tahun 2008 Tentang Perbankan Syariah

Wiroso, 2005. Penghimpunan Dana Dan Distribusi Hasil Usaha Bank Syariah. Jakarta : Grasindo

www.datacon.co.id diakses pada 23 Februari 2016

www.ojk.go.id diakses pada 26 November 2015

www.republika.co.id diakses pada 19 Februari 2016 